thirds of those on their list each year ${ }^{7}$ (though probably a smaller proportion of those at highest risk) such advice given carefully to every patient might also greatly reduce the spread of HIV in the population. There remains a need for evaluating the most effective ways in which this can be done. Nevertheless, the matter is so urgent that this need must not be used as an excuse for inaction.

We thank Dr P Anderson and Dr R Mayon-White from the department of community medicine, Oxfordshire Health Authority, for allowing us to base our questionnaire on theirs. We also thank Dr J Cobb (district medical officer), Ms M Hobbs, Ms L Jones, Mrs V Mew, and Dr J Queenborough for their help and support.

\section{References}

1 Anonymous. AIDS, HIV and general practice [Editorial]. $\mathcal{F}$ R Coll Gen Pract 1987;37:289-90. 2 Adler MW. Care for patients with HIV infection and AIDS. Br Med f 1987;295:27-30.

3 Tillett HE, McEvoy M. Reassessment of predicted numbers of AIDS cases in the UK. Lancet 1986;ii:1104.
4 Searle ES. Knowledge, attitudes, and behaviour of health professionals in relation to AIDS. Lancet 1987;i:26-8.

5 Stevens AJH, Searle ES, Winyard GPA. AIDS and life years lost: one district's challenge. BrMed f 1987;294:572-3.

6 Acheson ED. AIDS: a challenge for the public health. Lancet 1986;i:662-6.

6 Acheson ED. AIDS: a challenge for the public health. Lancet 1986;i:662-6.

Wallace PG, Brennan PJ, Haines AP. Are general practitioners doing enough to promote healthy lifestyle? BrMed f 1987;294:940-2.

9 Russell MAH, Wilson C, Taylor C, Baker CD. Effect of general practitioners' advice against smoking. Br Med J 1979;ii:231-5.

10 Richmond R, Webster I. Evaluation of general practitioners' use of smoking intervention programme. Int f Epidemiol 1985;14:396-401.

11 Morton AD, McManus IC. Attitudes to and knowledge about the acquired immune deficiency syndrome: lack of a correlation. $\mathrm{Br} \mathrm{Med}$ f 1986;293:1212.

12 Pinching AJ. AIDS and the heterosexual epidemic. Br Med J 1987;294:1354.

13 Kingsley LA, Kaslow R, Rinaldo CR Jr, et al. Risk factors for seroconversion to human immunodeficiency virus among male homosexuals. Lancet 1987; i:345-9.

14 Milne R, Keen S. Fighting HIV and AIDS: East Berkshire's early experience. Health Trends (in press).

15 Wellings K. AIDS and the condom. Br Med f 1986;293:1259-60.

16 Kelly JA, St Lawrence JS. Cautions about condoms in prevention of AIDS. Lancet 1987;i:323.

17 Vessey MP, Mackintosh LV. Condoms and AIDS prevention. Lancet 1987;i:568

18 Comfort A. Preventing AIDS. BrMed f 1987;294:1356.

19 Wigersma L, Oud R. Safety and acceptability of condoms for use by homosexual men as a prophylactic against transmission of HIV during anogenital sexual intercourse. $\mathrm{Br} \mathrm{Med} \mathcal{f}$ 1987;295:94.

(Accepted 10 November 1987)

\title{
General practitioners and management of infection with HIV
}

\author{
PETER ANDERSON, RICHARD MAYON-WHITE
}

\begin{abstract}
General practitioners will have an increasingly important role in the management of patients with the acquired immune deficiency syndrome (AIDS) and infections with human immunodeficiency virus (HIV) as the numbers of cases increase. Altogether 280 general practitioners working in Oxfordshire were sent a postal questionnaire inquiring about their education, knowledge, current practice, and attitudes in relation to managing infections with HIV. Of the $235(84 \%)$ general practitioners who replied, nine out of 10 were giving advice about infection with HIV to their patients. One in two were testing patients for such infection, and one in four were caring for infected patients. Nevertheless, uncertainty remained about the risks of transmission of infection with HIV and general practitioners' knowledge of educational activities for their patients could be improved.

The introduction of a facilitator to work with general practitioners in managing patients with AIDS or infection with HIV is planned, especially to help general practitioners develop the skills needed for prevention.
\end{abstract}

\section{Introduction}

As the numbers of patients infected with human immunodeficiency virus (HIV) and with the acquired immune deficiency syndrome (AIDS) increase general practitioners will have an increasingly important role in screening for HIV antibody state, counselling

District Department of Community Medicine, Oxfordshire Health Authority, Manor House, Headington, Oxford OX3 9DZ

PETER ANDERSON, MSC, MRCGP, general practitioner and senior registrar in community medicine

RICHARD MAYON-WHITE, MRCP, FFCM, specialist in community medicine

Correspondence to: Dr Anderson. patients positive for HIV, and managing patients with AIDS. Although there have been some studies of doctors' and nurses' views about AIDS,,$^{1-3}$ little is known about the education, knowledge, current practice, and attitudes of general practitioners in relation to the management of infection with HIV. We undertook this study to obtain such information as a step to develop the prevention and treatment of these infections outside hospitals.

\section{Methods}

The sample comprised 280 general practitioners whose practice was in Oxfordshire. They were sent a postal questionnaire with a freepost return envelope during spring 1987. The questionnaire covered six main topics: education of the public (health education, educational material based in the practices, and dealing with patients' questions); professional education (of general practitioners and staff in the practice); screening for HIV antibody state; managing patients positive for HIV antibody; patients with AIDS, and attitudes to AIDS and infection with HIV

The component of the questionnaire concerned with professional education included a series of questions on educational activities undertaken by the general practitioners (attending meetings or seminars on AIDS and reading medical publications on AIDS) and a series of questions about seeking specialist advice or information about AIDS from clinics for genitourinary medicine and department of infectious disease. The number of educational activities was added together to give a maximum score of five, and the number of activities for seeking information was added together to give a maximum score of four.

The component of the questionnaire concerned with measuring doctors' attitudes to working with the issues of AIDS consisted of 10 questions to which the respondents were asked to indicate agreement on a seven point scale ranging from "strongly agree" to "strongly disagree." Responses to the 10 scales were added to give a combined overall attitude score. The scores were divided into equal numerical thirds: "low," "middle," and "high." Low indicated a less positive attitude towards working with patients with AIDS and high a more positive attitude.

\section{Results}

Altogether 235 general practitioners (84\%) replied. 


\section{PUBLIC EDUCATION}

Health education-Most of the doctors had seen and read some form of literature on health education distributed to the public (the Department of Health and Social Security's publication 195; the Health Education Council's publications 162; the leaflet from the British Medical Association and the British Broadcasting Corporation 94; and leaflets from the Terrence Higgins Trust 56).

Educational material based in practices-Altogether 134 doctors had displayed posters and educational material about AIDS in their practices, but fewer than one in 10 doctors had produced any information on AIDS specific to their practices (16) or had held any meetings or talks on AIDS for their patients $(21)$.

Patients' questions-Most of the doctors had been asked questions about AIDS by patients, at an average rate of five patients for each doctor in the previous month. The questions were primarily about the risk of infection with HIV and how to avoid it. Table I shows the doctors' knowledge about transmission of the virus causing AIDS. Although most were well informed about the means of transmission, they remained uncertain about its transmission by saliva, razors, oral sex, breast feeding, insect bites, dentists, and hairdressers. Table II shows the advice that doctors most frequently gave about reducing the risk of transmission of AIDS from sexual activity, drug use, and travel.

TABLE I-General practitioners' knowledge about transmission of virus causing AIDS

\begin{tabular}{lrrr}
\hline & Yes & No & $\begin{array}{r}\text { Don't } \\
\text { know }\end{array}$ \\
\hline Virus causing AIDS can be caught from: & & & \\
Social kissing & 2 & 228 & 5 \\
Saliva & 59 & 155 & 21 \\
Tears & 14 & 202 & 19 \\
Sharing cups & & 230 & 5 \\
Sharing razors & 179 & 33 & 23 \\
Vaginal intercourse & 226 & 7 & 2 \\
Anal intercourse & 235 & 202 & 19 \\
Mutual masturbation & 14 & 28 & 21 \\
Oral sex & 183 & 19 & 2 \\
Receiving blood & 214 & 725 & 7 \\
Vaccinations and immunisations & 23 & 14 & 5 \\
Mothers (to babies) & 216 & 108 & 80 \\
Breast feeding & 47 & 2 & 2 \\
Sharing needles & 231 & 186 & 35 \\
Insect bites & 14 & 228 & 5 \\
Swimming pools & 2 & 61 & 21 \\
Ear piercing & 153 & 124 & 38 \\
Dentists & 73 & 176 & 35 \\
Hairdressers & 24 & & \\
\hline
\end{tabular}

TABLE II-Numbers of general practitioners giving specific advice to patients to reduce risk of developing AIDS $(n=235)$

In relation to sex:
Avoid casual sex
Stick to one partner
Use condom
Practise safe sex
In relation to drugs:
Don't share needles
Don't use drugs
In relation to travel:
Avoid prostitutes
Avoid casual sex
Use condoms
Avoid receiving blood or blood products

\section{PROFESSIONAL EDUCATION}

General practitioners-Most of the doctors had undertaken some form of self education about AIDS (reading booklets from the Department of Health and Social Security 219; reading papers in journals 216; reading one or more of the British Medical Association's reports on AIDS 162; attending talks or seminars on AIDS 153; and inviting an expert to the practice to talk about AIDS 40. A smaller proportion of doctors, however, had sought advice or information about AIDS from specialists (genitourinary physicians 85 and community physicians or infectious disease physicians, or both, 19). One third of the doctors said that they would like further education in matters related to AIDS, particularly regular, up to date information, and half of them said that they would welcome someone to visit their practice to talk about AIDS.

Practice staff-Only six practices had a written policy on AIDS for the practice. Although two thirds of the general practitioners had held discussions about AIDS with the nurses in their practices, discussion with other members of staff was less common (district nurses 95, health visitors and reception staff each 87 , midwives 54, and domestic staff 14 . One third of the general practitioners had sent the nurses in their practices to meetings and talks about AIDS, but only seven had sent their reception staff to such meetings.

\section{SCREENING FOR INFECTION WITH HIV}

Half of the general practitioners usually took blood within the practice for assessment of HIV state, while the others referred patients elsewhere. One hundred and six of the practitioners $(90 \%)$ who took blood for tests for HIV said that they wore gloves, and six wore goggles; 106 of them also said that they counselled patients when they took the blood sample. Altogether 212 general practitioners said that they asked patients to make a follow up appointment to discuss the result of the test and its implications.

\section{MANAGING PATIENTS POSITIVE FOR HIV}

Altogether 63 general practitioners had at least one patient positive for HIV in their practices. One third of the doctors said that they usually counselled or would counsel patients positive for HIV, while the rest said that they usually referred or would refer such patients elsewhere for counselling. Most of the general practitioners thought themselves confident in advising patients positive for HIV on relevant activities (sexual activity 195 , drug use 190, domestic activity 186, pregnancy 143). One in six practices used special marks or tags on their records to identify patients positive for HIV, but only 13 practitioners had a protocol for following up such patients. Half the practitioners knew of self help groups to recommend to patients, but fewer than 50 knew of relevant self help literature.

\section{MANAGING PATIENTS WITH AIDS}

Twenty one general practitioners had helped care for one or more patients with AIDS. Nearly all the general practitioners thought that patients with AIDS should be managed at home between acute phases of illness, and half of them thought that some terminally ill patients could be managed at home. Nearly all practitioners thought that patients with AIDS who were acutely ill should be managed in a ward for infectious diseases. Nearly all practitioners believed that a hospice, either a general hospice or a hospice specifically for AIDS, would be an appropriate place for managing patients who were terminally ill and could not be managed at home. We asked the general practitioners what facilities they believed were necessary to manage patients with AIDS at home. Eighty of them mentioned ready access to specialist advice, 70 increased cover by district nurses, 38 provision of home nurses, and 33 provision of counsellors and increased education for themselves and for the carers at home.

\section{ATTITUDES TO WORKING WITH PATIENTS WITH AIDS}

Table III shows the general practitioners' attitudes to working with patients with AIDS. Although three quarters of the general practitioners thought that they had adequate knowledge about AIDS, only a third thought that they could counsel patients positive for HIV long term. Twenty six practitioners considered that there was little that they could do to help patients positive for HIV, and 85 thought that the best that they could offer such patients was referral to somebody else.

\section{RELATIONS AMONG VARIABLES ASSESSED WITH QUESTIONNAIRE}

We found a positive relation between doctors' attitudes in dealing with issues related to AIDS and both the amount of educational activities that the doctors themselves had undertaken (correlation coefficient $0.17, \mathrm{p}<0.01$ ) and the number of patients who had asked them questions about AIDS (correlation coefficient $0.22, \mathrm{p}<0.001$ ). The number of educational activities that the doctors had themselves undertaken was related only to the educational activities of their staff; it did not relate to aspects of public 
TABLE III-General practitioners' attitudes to working with patients with AIDS $(n=235)$

\begin{tabular}{|c|c|c|c|}
\hline & Disagree & $\begin{array}{l}\text { Neither } \\
\text { agree nor } \\
\text { disagree }\end{array}$ & Agree \\
\hline $\begin{array}{l}\text { I think I have a working knowledge of AIDS and } \\
\text { infections with HIV }\end{array}$ & 28 & 26 & 179 \\
\hline $\begin{array}{l}\text { I think I know enough about the factors that put people at } \\
\text { risk of developing infections with HIV } \\
\text { I think I know how to counsel patients positive for HIV }\end{array}$ & 14 & 16 & 205 \\
\hline long term & 99 & 49 & 87 \\
\hline I think I can appropriately advise my patients about HIV & 26 & 40 & 169 \\
\hline $\begin{array}{l}\text { I think I have the right to ask patients about their } \\
\text { sexual activities when necessary } \\
\text { I think I have the skills to ask a patient for any }\end{array}$ & 5 & 14 & 216 \\
\hline information that is relevant to infection with HIV & 28 & 38 & 169 \\
\hline $\begin{array}{l}\text { I think that the best I can offer patients positive for HIV } \\
\text { is referral to somebody else }\end{array}$ & 103 & 47 & 85 \\
\hline $\begin{array}{l}\text { for HIV } \\
\text { I often feel uncomfortable when talking about explicit }\end{array}$ & 183 & 26 & 26 \\
\hline $\begin{array}{l}\text { In general I think I can understand patients who are } \\
\text { In }\end{array}$ & 157 & 26 & 52 \\
\hline positive for HIV & 35 & 85 & 115 \\
\hline
\end{tabular}

education, knowledge about AIDS, screening for HIV state, or management of patients with infections with HIV or with AIDS.

The doctors' attitudes related to some aspects of public education and management of patients positive for HIV but did not relate to screening for HIV states. For example, none of the 61 low scorers provided information in their practice, whereas nine of the 64 high scorers $(14 \%)$ had provided information on preventing AIDS $\left(\chi^{2}=10.2, \mathrm{df}=2, \mathrm{p}<0.01\right)$. High scorers were more likely to counsel patients positive for HIV themselves and were more confident in advising them on life activities-for example, 10 of the 61 (16\%) low scorers usually counselled such patients themselves compared with 39 of the $64(61 \%)$ high scorers $\left.\left(\chi^{2}=43.9\right), d f=2, p<0.001\right)$, and 30 $(62 \%)$ of the low scorers felt confident in advising patients on sexual activity compared with $62(97 \%)$ of the high scorers $\left(\chi^{2}=29 \cdot 1, \mathrm{df}=2, \mathrm{p}<0 \cdot 001\right)$.

\section{Discussion}

Our main finding was the strong commitment of general practitioners, at least in this county, to solving the practical problems of infection with HIV. With nine out of 10 general practitioners giving advice, one in two testing patients, and one in four caring for infected patients, the general practitioners who responded to the questionnaire were already much concerned about AIDS. One theme, commented on in the questionnaire, was that AIDS should be seen as one of several fatal diseases, such as cancer, that require urgent attention for prevention and care. General practice has an important role in preventing AIDS from becoming a special problem managed in isolation.
To be effective in prevention and care general practitioners should have accurate knowledge. We found that they were uncertain about the risks of transmission, which may in turn reflect conflicting, ambiguous, or misreported statements by specialists. They also needed to improve their knowledge about educational materials for their patients, to provide both general health education for all those visiting their premises and specific advice for those found to be infected. These problems can be remedied in several ways. Firstly, we intended our survey to be an initial step in stimulating general practitioners to look for answers when the questionnaire showed gaps in their knowledge. Secondly, we plan to appoint a facilitator to work with them especially to help them develop the skills needed to prevent AIDS.

The dichotomy between those general practitioners who take blood for tests of HIV state and those who refer patients elsewhere, and similarly that between general practitioners who would counsel patients positive for HIV and those who would refer them elsewhere, illustrates another difficulty. We think that general practitioners should have a role in the early stages of HIV infection when the diagnosis is first made. If general practitioners think that they cannot handle blood from potentially infected patients or discuss the implications of a positive result how will they be able to care for patients during the later stages of the illness? Our survey may have exaggerated this dichotomy by asking hypothetical questions: such questions may be more readily answered if they arise in real life.

More community nurses trained in the care of patients with AIDS would help general practitioners. A combination of more district nurses with a few specialist nurses seems to be needed. General practitioners themselves need training, particularly in counselling skills. This survey could not determine whether the association between more educational activities and more positive attitudes was causal in either direction. This possibility, however, leads us to conclude that education on infection with HIV, including the education of doctors and nurses, must be extended.

The study was funded by this department. We thank the general practitioners for completing the questionnaires, Janet Robertson for clerical help, and Mary Timbrell for both clerical help and typing the manuscript.

\section{References}

1 Burrow GN. Caring for AIDS patients: the physician's risk and responsibility. Can Med Assoc $\mathcal{f}$ 1983;129:1181.

2 Douglas CJ, Calman CM. Homophobia among physicians and nurses: an empirical study. Hosp Community Psychiatry 1985;36:1309-11.

3 Searle ES. Knowledge, attitudes and behaviour of health professionals in relation to AIDS. Lancet 1986; ; $26-8$.

(Accepted 30 October 1987)
The subjoined memorial is being very extensively signed by patients and visitors at Maloja and Moritz. "We, the undersigned British subjects residing in the Engadine, pray the British Minister will petition the Federal Government of Switzerland to permit our own medical men to practise in this country, so that we may, in case of need, avail ourselves of the medical assistance of doctors of our own nationality. Many of us have come to this canton in search of health, with the express understanding that we could place ourselves under the medical care of English doctors, but in mid-winter the law of the Sanitätsrath at Coire has suddenly been put into operation, and our English compatriots are heavily fined and threatened with expulsion from the Canton of the Grisons for practising without being in possession of the Swiss diploma. Under these circumstances we beg the British Minister will represent to the Federal Government the desire named in this petition, and express at the same time that the action taken against our English doctors will prevent many English subjects availing themselves of the climate and attractions of this canton both in summer and winter, which deprivation they would feel acutely." A narrow and jealous policy in such a matter would operate very prejudicially to the interests of the locality, and no doubt the Federal Government will take this into consideration.

(British Medical fournal 1888;i:147)

A proposal has been brought before the Municipal Council of St. Petersburg to impose a poll tax of one rouble, in order to provide additional funds for hospital administration. The tax is estimated to produce about one million roubles $(£ 120,000)$; but the suggestion has not met with a favourable reception, and its adoption is doubtful.

(British Medical fournal 1888;i:29) 